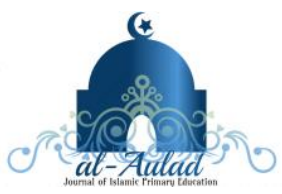

\title{
MENINGKATKAN HASIL BELAJAR MELALUI PEMBELAJARAN NUMBER HEAD TOGETHER
}

\author{
Siti Aisyah ${ }^{1}$ Vani Nurasyiah ${ }^{1}$ \\ ${ }^{1}$ Jurusan Pendidikan Guru Madrasah Ibtidaiyah, UIN Sunan Gunung Djati, Bandung, Indonesia \\ vani_25@yahoo.com
}

Naskah diterima: 1 Januari, 2018, direvisi: 14 Maret, 2018, diterbitkan: 31 Maret, 2018

\begin{abstract}
This study aims to determine the cognitive achievement of students before using cooperative learning model Numbered Heads Together (NHT) and to know the learning activities undertaken by teachers and students using the NHT model on science subjects. The research describing the picture of the process of learning science by using cooperative learning model NHT, and describe the cognitive learning outcomes of students after using NHT. The methodology in this research is the Classroom Action Research comprising the steps of planning, implementation, observation, and reflection that lasted for two cycles, with the subject of fifth-grade students of Islamic primary school Sirojul Subang district West Java Indonesia with 27 students, consisting of 13 girls and 14 boys. Based on the results of research analysis that the implementation of NHT model is well-implemented student cognitive learning outcomes in the first cycle obtained an average value of 76 with $74 \%$ learning completeness and in cycle II obtained an average value 91 with 100\% complete learning. Thus there is a significant improvement in the learning process using cooperative learning model type Numbered Heads Together on science subjects.
\end{abstract}

Keywords: cooperative learning, number hear together, sains, Islamic primary school

\begin{abstract}
ABSTRAK
Penelitian ini bertujuan untuk mengetahui hasil belajar kognitif siswa sebelum menggunakan model pembelajaran kooperatif tipe Numbered Heads Together, mendeskripsikan gambaran proses pembelajaran IPA dengan menggunakan model pembelajaran kooperatif tipe Numbered Heads Together, dan mendeskripsikan hasil belajar kognitif siswa setelah menggunakan model pembelajaran kooperatif tipe Numbered Heads Together. Metode penelitian yang digunakan dalam penelitian ini adalah Penelitian Tindakan Kelas (PTK) yang terdiri dari langkah perencanaan, pelaksanaan, observasi, dan refleksi yang berlangsung selama dua siklus, dengan subjek siswa kelas V MI Sirojul Islam Subang yang berjumlah 27 orang siswa. Berdasarkan hasil analisis penelitian bahwa penerapan model NHT terlaksana dengan baik hasil belajar kognitif siswa pada siklus I diperoleh nilai rata-rata 76 dengan ketuntasan belajar $74 \%$ dan pada siklus II diperoleh nilai rata-rata 91 dengan ketuntasan belajar mencapai 100\%. Dengan demikian ada peningkatan yang signifikan pada proses pembelajaran dengan menggunakan model pembelajaran kooperatif tipe Numbered Heads Together pada mata pelajaran IPA pokok bahasan cahaya dan sifat-sifatnya.
\end{abstract}

Kata Kunci: pembelajaran kooperatif, number head together, sains, madrasah ibtidaiyah

\section{PENDAHULUAN}

Kajian tentang manusia penting dalam kaitannya dengan pendidikan karena manusia adalah sebagai subyek dan obyek pendidikan. Pandangan tentang hakikat manusia akan mempengaruhi tujuan pendidikan dan pelaksanaan pendidikan. Dalam kamus besar Bahasa Indonesia, manusia diartikan sebagai makhluk yang berakal budi artinya mampu manguasai makhluk lain (Yahya, 2010). Dalam Undang-Undang No. 20 tahun 2003 (Sagala, 2012:3) pendidikan diartikan usaha sadar dan terencana untuk mewujudkan suasana belajar dan 
proses pembelajaran agar peserta didik secara aktif mengembangkan potensi dirinya untuk memiliki kekuatan spiritual keagamaan, pengendalian diri, kepribadian, kecerdasan, akhlak mulia, serta keterampilan yang diperlukan dirinya, masyarakat, bangsa dan Negara. Adapun tujuan pendidikan Indonesia tertulis pada Undang-Undang Republik Indonesia (UURI) Nomor 20 Tahun 2003 tentang Sistem Pendidikan Nasional (SPN) beserta peraturanperaturan pemerintah yang bertalian dengan pendidikan.

Merujuk pada UUSPN Nomor 20 Tahun 2003 untuk mencapai tujuan pendidikan nasional tersebut, pemerintah telah menyelenggarakan perbaikan-perbaikan peningkatan mutu pendidikan pada berbagai jenis dan jenjang. Namun fakta di lapangan belum menunjukkan hasil yang memuaskan. Masalah utama dalam pembelajaran pada pendidikan formal dewasa ini adalah masih rendahnya daya serap peserta didik. Hal ini tampak dari ratarata hasil belajar peserta didik yang senantiasa masih sangat memprihatinkan. Prestasi ini tentunya merupakan hasil kondisi pembelajaran yang masih bersifat konvensional dan tidak menyentuh ranah dimensi peserta didik itu sendiri, yaitu bagaimana sebenarnya belajar itu.

Menurut (Suprijono, 2014) bahwa hasil belajar adalah pola-pola perbuatan, nilai-nilai, pengertian-pengertian, sikap-sikap, apersepsi dan keterampilan. Maka, hasil belajar adalah perubahan perilaku secara keseluruhan bukan hanya salah satu aspek potensi kemanusiaan saja. Guru dituntut menguasai dan menggunakan dengan tepat model, metode, atau teknik pembelajaran dalam proses belajar mengajar agar tercapai tujuan pembelajaran yang diinginkan yaitu meningkatkan hasil belajar siswa. Guru merupakan suatu faktor yang berperan penting dalam proses belajar siswa, meskipun tidak setiap perbuatan siswa merupakan akibat guru mengajar. Oleh karena itu, sebagai figur sentral guru harus mampu menetapkan strategi pembelajaran yang tepat, sehingga dapat mendorong terjadinya perbuatan siswa yang aktif, produktif dan efisien.

Berbagai upaya yang dilakukan oleh guru untuk meningkatkan hasil belajar khususnya pada mata pelajaran Ilmu Pengetahuan Alam (IPA) di Madrasah Ibtidaiyah (MI). Guru IPA perlu memahami dan mengembangkan strategi dalam pembelajaran IPA, sehingga dapat memberikan aktivitas nyata bagi siswa dengan berbagai obyek yang akan dipelajari. IPA merupakan ilmu yang berhubungan dengan gejala-gejala alam dan kebendaan yang sistematis, tersusun secara teratur, berlaku secara umum, berupa kumpulan hasil observasi, dan eksperimen. Dengan demikian sains tidak hanya sebagai kumpulan tentang benda atau mahluk hidup, tetapi tentang cara kerja, cara berpikir, dan cara memecahkan masalah (Djumhana, 2009).

Proses pembelajaran IPA khususnya pada anak MI harus menekankan pada pemberian pengalaman secara langsung pada peserta didik untuk mengembangkan kompetensi agar menjelajahi dan memahami alam sekitar, yang pada akhirnya mereka menemukan sendiri konsep materi pelajaran yang sedang dipelajarinya. Selain itu, pembelajaran IPA diarahkan untuk memberi pengalaman langsung sehingga dapat membantu peserta didik untuk memperoleh pemahaman yang lebih mendalam mengenai alam sekitar. Pembelajaran IPA merupakan upaya guru dalam membelajarkan siswa melalui penerapan berbagai model pembelajaran yang dipandang sesuai dengan karakteristik anak MI (Djumhana, 2009). IPA merupakan ilmu pengetahuan yang mempunyai obyek, menggunakan metode ilmiah, dan merupakan dasar teknologi, sering disebut - sebut sebagai tulang punggung pembangunan. Dalam artian kedudukan IPA dapat dikatakan sebagai pengetahuan dasar pada teknologi. Untuk itu kegiatan belajar mengajar IPA di Madrasah Ibtidaiyah harus diajarkan dengan cara yang tepat, sehingga IPA menjadi suatu mata pelajaran yang memberikan kesempatan berpikir kritis. 
Berdasarkan hasil studi pendahuluan di Madrasah Ibtidaiyah Sirojul Islam Subang menunjukkan bahwa hasil belajar IPA yang belum tuntas karena belum mencapai KKM (Kriteria Ketuntasan Minimal) yang telah ditentukan yaitu 65. Salah satu faktor penyebabnya guru lebih banyak berceramah, sehingga siswa menjadi lebih cepat bosan dan menyebabkan hasil belajar IPA rendah. Ditambah dengan pendapat siswa bahwa pelajaran IPA dianggap sulit. Sehingga tidak tertarik untuk belajar. Hal ini berdampak pada rendahnya hasil belajar yang diperoleh siswa. Rendahnya hasil belajar siswa juga terjadi pada Ujian Akhir Sekolah (UAS) untuk pelajaran IPA kelas V dengan nilai rata-rata 60. Hal tersebut diperkirakan karena kurangnya pemahaman siswa terhadap konsep pembelajaran IPA. Perlu diketahui bahwa tingkat pemahaman tiap-tiap siswa tidak sama, sehingga kecepatan siswa dalam mencerna bahan pengajaran berbeda. Proses pembelajaran IPA kurang adanya penguatan pendekatan, media dan model pembelajaran yang tepat, sehingga guru yang cenderung aktif dan siswa pasif. Kebiasaan bersikap pasif dalam pembelajaran dapat mengakibatkan sebagian besar siswa takut dan malu bertanya pada guru mengenai materi yang kurang dipahami.

Proses pembelajaran IPA diharapkan siswa lebih aktif, sehingga akan berdampak pada ingatan siswa tentang apa yang dipelajari. Suatu konsep akan mudah dipahami dan diingat oleh siswa bila konsep tersebut disajikan melalui prosedur dan langkah-langkah yang tepat, jelas, dan menarik. Keaktifan dan pemahaman siswa dalam proses pembelajaran merupakan salah satu faktor yang mempengaruhi keberhasilan dalam belajar. Penanganan permasalahan seperti diuraikan di atas memerlukan suatu upaya praktis yang bertujuan memperbaiki proses pembelajaran kearah yang lebih baik. Salah satu upaya yang dimaksud adalah dengan penerapan model pembelajaran kooperatif tipe Numbered Heads Together (NHT). Model pembelajaran kooperatif merupakan salah satu model pembelajaran dengan pendekatan kontekstual, yang artinya peserta didik pada kegiatan pembelajaran menggunakan sistem belajar kelompok (Selviana, 2013).

Suherman (Pradnyani, 2013:4) keunggulan pembelajaran kooperatif adalah mencakup suatu kelompok kecil siswa yang bekerja sebagai sebuah tim untuk menyelesaikan sebuah masalah, menyelesaikan suatu tugas, atau mengerjakan sesuatu untuk mencapai tujuan bersama. NHT merupakan model yang menyenangkan dan dapat memotivasi siswa untuk aktif bila diterapkan di kelas. Siswa diajak untuk berkompetisi mewakili kelompoknya. Siswa diberi topi dengan nomor dikepalanya. Setiap siswa dalam kelompok bertangggung jawab untuk perolehan skor di kelompoknya dan menjadi tim yang berhasil (Saefudin, 2013). Model pembelajaran kooperatif tipe NHT selain meningkatkan kerja sama siswa, NHT juga bisa diterapkan untuk semua mata pelajaran dan tingkatan kelas (Huda, 2014:203). Dengan demikian NHT cocok diterapkan pada mata pelajaran IPA. Adapun kelebihan model pembelajaran NHT yaitu siswa dapat melakukan diskusi dengan sungguhsungguh dan siswa yang pandai dapat mengajari siswa yang kurang pandai. Sedangkan, kekurangannya yaitu adanya kemungkinan nomor yang dipanggil, dipanggil lagi oleh guru dan tidak semua anggota kelompok dipanggil oleh guru (Salahudin, 2015).

\section{METODOLOGI}

Metode yang digunakan dalam penelitian ini adalah Penelitian Tindakan Kelas (PTK), Penelitian ini merupakan salah satu upaya guru atau praktisi dalam bentuk berbagai kegiatan yang dilakukan untuk memperbaiki dan meningkatkan mutu pembelajaran di kelas. Jenis data terdiri dari data kualitatif dan kuantitatif. Data kualitatif digunakan untuk mengetahui gambaran proses keterlaksanaan model pembelajaran kooperatif tipe NHT yang telah diperoleh dari lembar observasi siswa. Data kuantitatif diperoleh dari hasil tes menggunakan 
model pembelajaran kooperatif tipe NHT yang diasumsikan dapat terjadi peningkatan hasil belajar siswa dikelas.

Penelitian dilaksanakan di Madrasah Ibtidaiyah Sirojul Islam yang bertempat di Tanjungsiang kabupaten Subang Jawa Barat. Subjek dalam penelitian ini adalah siswa kelas V MI Sirojul Islam dengan jumlah siswa keseluruhan 27 orang, terdiri dari 13 orang perempuan dan 14 orang laki-laki. Penelitian dilaksanakan melalui proses empat tahap, yaitu; Perencanaan (plan), Pelaksanaan Tindakan (action), Pengamatan (observation), dan Refleksi (reflection). Pertama, pada tahap perencanaan guru merencanakan hal-hal sebagai berikut: 1) Menyusun Rencana Pelaksanaan Pembelajaran (RPP) pokok bahasan Cahaya dan Sifat-sifatnya, 2) Merumuskan tujuan yang ingin dicapai, 3) Menyiapakan model pemebelajaran yang akan diterapkan dalam KBM, 4) Membuat instrument penilaian berupa tes pilihan ganda yang harus dikerjakan setelah mengikuti proses pembelajaran. Kedua, pada tahap pelaksanaan guru melasanakan tindakan sesuai dengan rencana, ditahap ini pula proses pembelajaran diamati oleh seorang observer. Ketiga, tahap pengamatan dilakukan bersamaan dengan pelaksanaan tindakan. Pada tahap ini observer mengumpulkan berbagai informasi di kelas dari mulai aktivitas siswa sampai pada aktivitas guru pada saat pelaksanaan tindakan, dengan mengacu pada lembar observasi yang telah disusun sebelumnya. Keempat, tahap refleksi dimana guru melakukan evaluasi terhadap pelaksanaan tindakan, dan melakukan tindak lanjut untuk siklus berikutnya.

Teknik pengumpulan data dalam penelitian ini menggunakan observasi, dokumentasi dan tes. Observasi dilakukan untuk menghimpun data mengenai aktivitas guru dan siswa pada saat proses pembelajaran berlangsung. Dokumentasi digunakan untuk memperoleh data berupa dokumen yan berhubungan dengan penelitian, diantaranya; catatan harian siswa, absensi kehadiran siswa, daftar nilai dan foto-foto pada saat pelaksanaan tindakan. Tes diberikan untuk menilai kemampuan IPA dengan penerapan model pembelajaran kooperatif tipe NHT. Adapun tes yang digunakan disini adalah tes pilihan ganda sebanyak 10 soal.

Adapun analisis data yang dilakukan dalam penelitian ini yaitu analisis hasil observasi dengan menggunaan rumus:

Rata-rata aktivitas guru $=\frac{\text { Skor yang diperoleh }}{\text { Skor maksimal }} \times 100 \%$

Rata-rata aktivitas siswa $=\frac{\text { Skor yang diperoleh }}{\text { Skor maksimal }} \times 100 \%$

Sedangkan pengolahan data tes pilihan ganda terkait mata pelajaran IPA dengan menggunakan model pembelajaran kooperatif tipe NHT, menggunakan rumus sebagai berikut:

Ketercapaian individu: $\frac{\text { Skor yang diperoleh siswa }}{\text { Skor maksimal }} \times 100 \%$

Tabel 1. Interprestasi Keterlaksanaan

\begin{tabular}{|c|c|c|}
\hline Persentase & Bobot & Kategori \\
\hline$\leq 54$ & 0 & Sangat kurang \\
\hline $55-59$ & 1 & Kurang \\
\hline $60-75$ & 2 & Sedang \\
\hline $76-85$ & 3 & Baik \\
\hline $86-100$ & 4 & Sangat baik \\
\hline
\end{tabular}

Sumber: Purwanto (2009, p.103)

Tabel di atas merupakan merupakan interpretasi dari perolehan skor rata-rata untuk aktivitas dan tes unjuk kerja. 


\section{HASIL DAN DISKUSI}

a. Hasil Belajar Siswa pada Pra Siklus

Berdasarkan hasil Pre Test mata pelajaran IPA pokok bahasan cahaya dan sifatsifatnya sebelum menggunakan model pembelajaran kooperatif tipe NHT, diperoleh ketuntasan belajar sebesar $48 \%$ dari 27 siswa hanya 13 siswa yang memperoleh nilai kurang dari 65. Hasil ini menunjukkan hasil belajar kognitif siswa masih rendah dan ketuntasan belajar siswa masih di bawah KKM yang ditentukan oleh sekolah yaitu 65. Aspek ketercapaian yang belum maksimal dikarenakan sebelum dilakukan pembelajaran siswa kelas V MI Sirojul Islam guru masih mendominasi dalam proses pembelajaran sehingga siswa menjadi pasif. Salah satu faktor yang menyebabkan siswa bersikap pasif karena minimnya pengetahuan guru tentang model-model pembelajaran, hal tersebut membuat siswa tidak belajar secara maksimal, guru saja yang memberikan materi sedangkan siswa hanya duduk dan mendengarkan penjelasan dari guru sehingga menyebabkan hasil belajar siswa rendah. Salah satu model pembelajaran yang dapat meningkatkan aktivitas dan hasil belajar siswa adalah model pembelajaran kooperatif tipe NHT sesuai dengan pendapat Jayanti (2014) bahwa NHT merupakan salah satu tipe pembelajaran kooperatif yang menekankan pada struktur-struktur khusus yang dirancang untuk mempengaruhi pola-pola interaksi siswa dan memiliki tujuan untuk meningkatkan penguasaan isi akademik.

b. Aktivitas Guru dan Siswa pada Siklus I

Aktivitas guru selama pembelajaran menggunakan model pembelajaran NHT pada siklus I termasuk kedalam kriteria sangat baik dengan perolehan nilai sebesar $83 \%$ dan indikator yang belum tercapai sebesar $17 \%$. Aktivitas siswa selama mengikuti kegiatan pembelajaran pada siklus I termasuk kedalam kategori sangat baik dengan perolehan nilai sebesar $90 \%$. Indikator yang belum tercapai sebesar $10 \%$. Aspek ketercapaian yang masih kurang maksimal pada siklus I ini dikarenakan masih kurangnya aktivitas belajar siswa dengan menggunakan model yang diterapkan oleh guru, karena penataan ruang belajar yang kurang efektif dan siswa masih merasa asing dengan model pembelajaran kooperatif tipe NHT, pembelajaran masih terasa kurang menyenangkan dan materi tidak tersampaikan dengan maksimal karena masih ada tahapan-tahapan model pembelajaran NHT yang belum tersampaikan. Oleh karena itu, aktivitas guru dan siswa masih harus ditingkatkan pada siklus II agar seluruh tahapan dapat tersampaikan secara maksimal.

c. Aktivitas Guru dan Siswa pada Siklus II

Aktivitas guru selama pembelajaran menggunakan model pembelajaran kooperatif tipe NHT pada siklus II termasuk dalam kriteria sangat baik dengan perolehan nilai mencapai 100\%. Hal ini menunjukan bahwa ketercapaian aktivitas guru pada siklus II sudah mencapai sempurna. Aktivitas siswa selama mengikuti kegiatan pembelajaran pada siklus II termasuk kedalam kategori sangat baik dengan perolehan nilai sebesar $100 \%$. Terlihat dari aspek ketercapaian pada seluruh indikator siklus II yaitu $100 \%$ sedangkan indikator yang belum tercapai sebesar $0 \%$. Oleh karena itu, aktivitas siswa cukup dilakukan sampai tindakan pada siklus II ini. Aspek ketercapaian yang sudah memenuhi kriteria sangat baik pada siklus II ini dikarenakan aktivitas belajar siswa dengan menggunakan model yang diterapkan oleh guru sudah berjalan dengan maksimal. Penataan ruang belajar yang sudah nyaman dan siswa sudah tidak merasa asing lagi dengan model pembelajaran NHT, sehingga kegiatan pembelajaran jadi menyenangkan dan materi tersampaikan dengan maksimal. 
Tabel 1. Peningkatan Aktivitas Guru dan Siswa

\begin{tabular}{|c|c|c|c|c|}
\hline No & Siklus & Guru/Siswa & Rata-Rata & Kriteria \\
\hline 1 & \multirow{2}{*}{ I } & Guru & 83 & Sangat Baik \\
\cline { 4 - 5 } 2 & & Siswa & 90 & Sangat Baik \\
\cline { 3 - 5 } 3 & \multirow{2}{*}{ II } & Guru & 100 & Sangat Baik \\
\cline { 3 - 5 } 4 & & Siswa & 100 & Sangat Baik \\
\cline { 3 - 5 } & & \multicolumn{2}{|c}{} \\
\hline
\end{tabular}

Berdasarkan tabel 1 aktivitas guru pada setiap siklusnya menjadi meningkat dari rata-rata 83 di siklus I menjadi 100 pada siklus II. Begitupun dengan aktivitas siswa di siklus I dari ratarata 90 menjadi 100. Kriteria tersebut berada pada kategori sangat baik.

d. Hasil Belajar Kognitif Siswa pada Siklus I

Hasil belajar kognitif siswa pada siklus I dapat disimpulkan bahwa perolehan nilai ratarata 76 termasuk dalam kriteria baik. Sedangkan ketuntasan klasikal sebesar $74 \%$ atau dari 27 siswa masih ada 11 siswa yang dikatakan belum tuntas belajar sehingga dapat dikatakan dalam kategori baik. Penelitian tindakan yang dilakukan pada siklus I dianggap belum berhasil karena meskipun nilai rata- rata sudah termasuk kriteria baik yaitu sebesar 76 tapi masih ada 11 siswa yang belum tuntas yaitu nilainya belum mencapai nilai KKM yang ditentukan yaitu 65. Dari data yang telah diuraikan penelitian pada siklus I harus dilanjutkan ke siklus II dan diadakan perbaikan mutu pembelajaran oleh guru pada siklus II.

e. Hasil Belajar Kognitif Siswa pada Siklus II

Hasil belajar kognitif siswa pada siklus II terjadi peningkatan yang signifikan. Hal ini dapat dilihat dari perolehan rata- rata siswa yang mencapai angka 91 sehingga termasuk kedalam kriteria sangat baik dan sudah memenuhi angka KKM yang telah ditentukan. Ketuntasan belajar siswa yang mencapai angka 100\%, artinya 27 siswa telah tuntas belajar.

Tabel 2. Peningkatan Hasil Belajar Kognitif Siswa

\begin{tabular}{|c|c|c|c|}
\hline No & Keterangan & Rata-Rata & Ketuntasan Belajar \\
\hline 1 & Pre test & 64 & $48 \%$ \\
\hline 2 & Siklus I & 76 & $74 \%$ \\
\hline 3 & Siklus II & 91 & $100 \%$ \\
\hline
\end{tabular}

Tabel 2 menunjukkan bahwa hasil belajar siswa pada saat pre test mencapai nilai ratarata 64 , jadi hanya $48 \%$ dari seluruh siswa yang tuntas belajar. Sedangkan pada siklus I nilai rata-rata meningkat menjadi 76 , sehingga ketuntasan belajar menjadi $74 \%$ dari keseluruhan siswa. Peningkatan yang signifikan terjadi pada siklus II dengan nilai rata-rata 91 dan seluruh siswa tuntas belajarnya dengan nilai ketuntasan belajar sebesar $100 \%$. Peningkatan ketuntasan ini dapat dilihat pada grafik di bawah ini: 


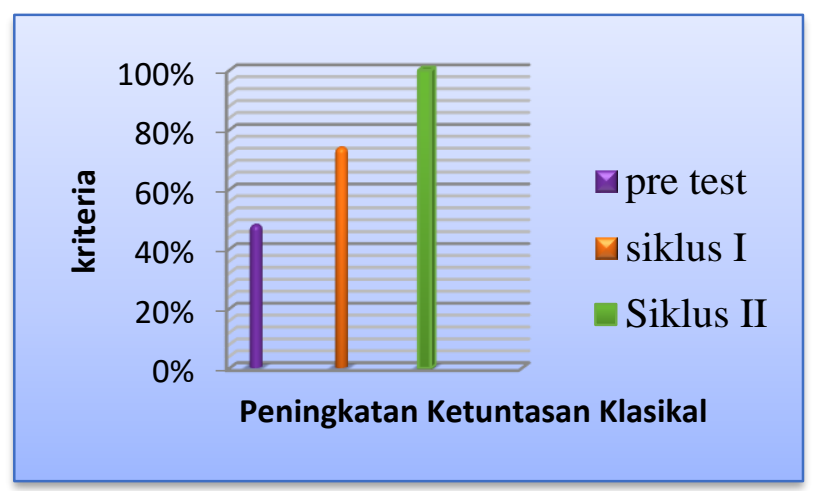

Gambar 1. Peningkatan Ketuntasan Klasikal

Berdasarkan analisis dari hasil penelitian di atas, dapat disimpulkan bahwa melalui model pembelajaran kooperatif tipe NHT, proses pembelajaran menjadi lebih baik dan hasil belajar IPA siswa kelas V MI Sirojul Islam Subang pada pokok bahasan cahaya dan sifatsifatnya dapat ditingkatkan, sehingga ketuntasan belajar siswa sesuai dengan yang diharapkan. Peningkatan yang dihasilakan setelah menggunakan model pemebelajaran kooperatif tipe NHT dimana masing-masing siklus menunjukkan peningkatan yang sangat baik. Hal ini sesuai dengan pendapat Sudjana (2008) hasil belajar adalah kemampuankemampuan yang dimiliki siswa setelah ia menerima pengalaman belajaranya. Kegiatan pembelajaran IPA dilakukan dengan menggunakan model pembelajaran kooperatif tipe NHT untuk menelaah materi yang tercakup dalam suatu pelajaran dan mengecek pemahaman siswa dengan semangat kerjasama. Hal ini sesuai dengan pendapat Kurniasih (2015) bahwa model NHT dapat mengembangkan rasa saling memiliki dan kerjasama serta dapat meningkatkan prestasi belajar siswa. Sehingga hipotesis tindakan yang diajukan peneliti terjawab bahwa dengan menggunakan model pembelajaran kooperatif tipe NHT dapat meningkatkan hasil belajar kognitif siswa pada mata pelajaran IPA pokok bahasan cahaya dan sifat-sifatnya.

\section{KESIMPULAN}

Hasil belajar kognitif IPA siswa sebelum menggunakan model pembelajaran kooperatif tipe NHT pada pokok bahasan cahaya dan sifat-sifatnya di kelas V MI Sirojul Islam Subang diperoleh nilai rata-rata 64 dan ketuntasan belajar sebesar 48\% dari 27 siswa hanya 13 siswa yang memperoleh nilai lebih dari 65 . Hasil observasi aktivitas guru pada siklus I termasuk kedalam kriteria sangat baik dengan perolehan nilai sebesar $83 \%$ dan indikator yang belum tercapai sebesar $17 \%$ sedangkan hasil observasi aktivitas siswa pada siklus I termasuk kedalam kategori sangat baik dengan perolehan nilai sebesar 90\%. Hasil observasi aktivitas guru pada siklus II termasuk dalam kriteria sangat baik dengan perolehan nilai mencapai 100\%. Hal ini menunjukan bahwa ketercapaian aktivitas guru pada siklus II sudah mencapai sempurna. Pada siklus II aktivitas siswa termasuk kedalam kategori sangat baik dengan perolehan nilai sebesar $100 \%$. Hasil belajar kognitif IPA siswa dengan menggunakan model pembelajaran kooperatif tipe NHT siklus I dapat disimpulkan perolehan nilai rata- rata 76 termasuk dalam kriteria baik sedangkan ketuntasan klasikal sebesar 74\%. Hasil belajar kognitif siswa pada siklus II terjadi peningkatan yang signifikan. Hal ini dapat dilihat dari perolehan rata- rata siswa yang mencapai angka 91 sehingga termasuk kedalam kriteria sangat baik. Ketuntasan belajar siswa yang mencapai angka $100 \%$. 


\section{DAFTAR PUSTAKA}

Basri, H. (2013). Landasan Pendidikan. Bandung: Pustaka Setia.

Djumhana, N. (2009). Pembelajaran Ilmu Pengetahun Alam. Jakarta: Direktorat Jendral Pendidikan, Departemen Agama RI.

Hayati, T. (2013). Statistika Pendidikan. Bandung: Insan Mandiri.

Hayati, T. (2014). Evaluasi Pembelajaran. Bandung: Insan Mandiri.

Saefudin, A \& Berdiati, I. (2013). Pembelajaran Bahasa Indonesia di SD/MI. Bandung: Insan Mandiri.

Salahudin, A. (2015). Penelitian Tindakan Kelas. Bandung: Pustaka Setia

Selviana, dkk. (2013). Penerapan Model Pembelajaran Kooperatif Tipe Numbered Heads Together untuk Meningkatkan Hasil Belajar Mata Pelajaran Matematika. Jurnal. Tidak diterbitkan. Program Studi Pendidikan Guru Sekolah Dasar FKIP Universitas Pakuan.

Sudijono, A. (2011). Pengantar Statistik Pendidikan. Jakarta: PT Rajagrafindo Persada. Suprijono, A. (2014). Cooperative Learning. Yogyakarta: Pustaka Pelajar.

Yahya, M. (2010). Pengantar Pendidikan. Bandung: Solo. 